\title{
Aurora B/C Kinase Inhibitor GSK1070916A
}

National Cancer Institute

\section{Source}

National Cancer Institute. Aurora B/C Kinase Inhibitor GSK1070916A. NCI Thesaurus. Code C91081.

An ATP-competitive inhibitor of the serine/threonine kinases Aurora B and C with potential antineoplastic activity. Aurora B/C kinase inhibitor GSK1070916A binds to and inhibits the activity of Aurora B and C, which may result in inhibition of cellular division and a decrease in the proliferation of tumor cells that overexpress the Aurora kinases B and C. Aurora kinases play essential roles in mitotic checkpoint control during mitosis, and are overexpressed by a wide variety of cancer cell types. 